\title{
Diffusion and sorption of allyl isothiocyanate in the process of fumigation of maize
}

\author{
Juliana L. Paes ${ }^{1}$, Lêda R. A. Faroni ${ }^{1}$, Marcio A. Martins ${ }^{1}$, 0 nkar D. D hingra ${ }^{2} \&$ Tales A. Silva $^{1}$
}

\section{ABSTRACT}

The purpose of this work was to evaluate the transport of allyl isothiocyanate (AITC) by means of the sorption mechanism and the diffusion of AITC through maize grains. The experimental procedure to study the sorption mechanism was conducted by injection of AITC in glass flasks containing the grains. Kinetic models of zero, first and second order were fitted to AITC concentration data, with the purpose of determining the sorption rate $(\mathrm{k})$. For the study of diffusion, a prototype was utilized in which the components are a gas chamber and a cylindrical column in which the grains were stored. At the interval of $110 \mathrm{~min}$, samples in the chamber and in the column were collected, which were immediately injected into the gas chromatograph. In order to determine the effective diffusion coefficient $\left(D_{\mathrm{ef}}\right)$ of AITC through maize grains, the term referring to the sorption rate was added to the diffusion equation. The kinetic model of the first order was the one that best fitted the experimental data for the sorption mechanism, and $\mathrm{k}$ was $6.26 \times 10^{-4} \mathrm{~s}^{-1}$. The $\mathrm{D}_{\text {ef }}$ of AITC through grains was $7.2 \times 10^{-3} \mathrm{~cm}^{2} \mathrm{~s}^{-1}$. It was concluded that the transport of AITC through maize grains is slow, due to the low value of $D_{\text {ef }}$ and high sorption rate of this component by the grains.

Key words: fumigant, effective diffusion coefficient, sorption rate

\section{Difusão e sorção do isotiocianato alilo no processo de fumigação do milho}

\section{RESU MO}

N este trabalho o propósito foi avaliar o transporte do isotiocianato alilo (AITC), por meio do estudo do mecanismo de sorção e da difusão do AITC, nos grãos de milho. 0 procedimento experimental para 0 estudo da sorção foi conduzido pela injeção de AITC em frascos de vidro contendo os grãos. Modelos cinéticos de ordem zero, de primeira e de segunda ordem, foram ajustados aos dados de concentração do AITC com a finalidade de determinar a taxa de sorção (k). Para o estudo da difusão utilizou-se um protótipo em que os componentes são uma câmara de gás e uma coluna cilíndrica, para contenção dos grãos. A cada 110 min amostras na câmara e na coluna foram coletadas e imediatamente injetadas no cromatógrafo a gás. Para determinar o valor do coeficiente efetivo de difusão $\left(D_{\text {ef }}\right)$ do AITC através de grãos de milho adicionou-se, à equação de difusão, o termo referente à taxa de sorção. 0 modelo cinético, foi o de primeira ordem e $\mathrm{k}$ foi $6,26 \times 10^{-4} \mathrm{~s}^{-1}$. O $\mathrm{D}_{\text {ef }}$ do AITC através dos grãos, foi de $7,2 \mathrm{x}$ $10^{-3} \mathrm{~cm}^{2} \mathrm{~s}^{-1}$. Concluiu-se que o transporte do AITC por meio dos grãos de milho é lento devido ao baixo valor do $D_{\text {ef }}$ e à elevada taxa de sorção deste componente pelos grãos.

Palavras-chave: fumigante, coeficiente efetivo de difusão, taxa de sorção 


\section{INTRODUCTION}

Over the last decades, the fumigant insecticides phosphine and methyl bromide have been utilized for the control of insect pests in stored grains (Zettler \& Arthur, 2000). However, the use of phosphine has been restricted due to the possibility of development of resistance in pest populations (Pimentel et al., 2007), and the utilization of methyl bromide has been limited because it is considered to be a depleting agent of the ozone layer (Bell, 2000). Consequently, there is an increasing interest of researchers in developing new insecticides for the control of insect pests in stored grains (Papachristos \& Stamopoulos, 2004; Almeida et al., 2005; Negahban et al., 2007; Rozado et al., 2008; Pereira et al., 2008; Capps et al., 2010). Among the existing options, allyl isothiocyanate (AITC), the main component of the mustard essential oil, can act as a fumigant.

Allyl isothiocyanate is utilized as a spice and a preserver by the food industry and is classified as generally regarded as safe (GRAS) by the Food and Drug Administration (FDA) of the United States (Isshiki et al., 1992; Mari et al., 2003; Dhingra et al., 2004). In the agricultural sciences, AITC was effective when utilized as a fumigant in the control of insect pests Lasioderma serricorne (Fabricius) (Coleoptera: Anobiidae), Tribolium confusum (Jacquelin du Val) (Coleoptera: Tenebrionidae) (Worfel et al., 1997), Ryzopertha dominica (Fabricius) (Coleoptera: Bostrichidae) (Tsao et al., 2002), Sitophilus zeamais (Motschulsky) (Coleoptera: Curculionidae) and Liposcelis entomophila (Enderlein) (Psocoptera: Liposcelididae) (Wu et al., 2009).

During research on new types of fumigants, in addition to evaluating their effectiveness for control of insect pests and their effect on grain quality, it is essential to study the transport by diffusion of gas through grain bulks. In this type of study, the effective diffusion coefficient is the main parameter to be determined, as it indicates the velocity of percolation of the gas through the medium due to the concentration gradient (Cremasco, 2002). The effective diffusion coefficient of a fumigant is related to the sorption of gas by grain bulks. The importance of considering the sorption mechanism lies in the fact that a fumigant highly sorbed by the medium will take longer to be transported through grain bulks. In addition, the understanding of the sorption mechanism of fumigants will help in determining the appropriateness of gas concentrations, given that the concentration level is reduced due to the sorption of fumigant by grain bulks and, therefore, avoid fumigation failure and/or the development of insect pest resistance (Weller, 2002).

Considering the influence of the sorption on gas diffusion, it is important to include the sorption rate term in the diffusion equation. Alagusundaram et al. (1996), studying the diffusion of carbon dioxide through wheat bulk, concluded that a diffusion model that takes into account the effect of sorption will predict, with higher precision, the distribution of the gas into the grain bulks. Also within this context, Shunmugam et al. (2005) added the sorption rate term in the diffusion equation to determine the effective diffusion coefficient of carbon dioxide through wheat, barley, and canola bulks.
Therefore, the aim of this research was to evaluate the transport of allyl isothiocyanate using the sorption rate and the effective diffusion coefficient of AITC through maize grains during the process of fumigation.

\section{MATERIAL AND METHODS}

The experiments were conducted in the Pre-Processing and Storage of Agricultural Products Laboratory of the Agricultural Engineering Department of the Federal University of Viçosa DEA/UFV, in Viçosa, Minas Gerais. Maize grains were obtained from Experimental Area of Agronomy of the Federal University of Viçosa. The grains were harvested and threshed mechanically.

Maize grains at moisture content of $13 \%$ wet basis, porosity of $40 \%$, and temperature of $25^{\circ} \mathrm{C}$ were used in the experiments. The moisture content of the grains was determined by aircirculated drier standard method, according to ASAE (2000), which describes the drier utilization with forced air circulation at $103 \pm 1{ }^{\circ} \mathrm{C}$ during $72 \mathrm{~h}$. The porosity was obtained as a function of the bulk density $\left(\rho_{\mathrm{b}}\right)$ and true density $\left(\rho_{\mathrm{t}}\right)$ according to Mohsenin (1986) (Eq. 1).

$$
\varepsilon=\left[1-\left(\frac{\rho b}{\rho t}\right)\right]
$$

The bulk density of grains was determined through a hectoliter balance, with capacity for a quarter liter, in three repetitions. The true density was determined according to the methodology of volume complementation as described by Moreira et al. (1985) and using soybean vegetable oil as the liquid medium. The mustard essential oil, with $90 \%$ of allyl isothiocyanate, was supplied by the Pettine Química Fina Company.

Experimental procedure for the study of sorption mechanism

Maize grains (220.97 g) were conditioned into an $800 \mathrm{~mL}$ glass flask and the flask was closed with a metallic lid. Using a rubber septum, a silicone tube that was coupled to one of the outlets of a U-tube water manometer was connected to the flask lid. The other outlet of the manometer was kept open towards the environment. After the closing and sealing of the flask, it $15 \mathrm{~mL}$ of AITC saturated vapor was injected. The same procedure was performed without the presence of the AITC in order to investigate the influence of the gaseous exchange between grains and intergranular air, which also causes system pressure modification. The pressure difference in each system was recorded every $10 \mathrm{~min}$ until $130 \mathrm{~min}$ were completed. All the experiments were replicated three times.

The AITC concentration per unit of grain mass was calculated using the universal gas law (Eq. 2).

$$
\mathrm{C}=\frac{\Delta \mathrm{P}^{\prime} \mathrm{VM}}{\mathrm{RTM}_{\mathrm{g}}}
$$

in which: 
C - AITC concentration per unit of grain mass, $\mathrm{g} \mathrm{kg}^{-1}$

$\Delta \mathrm{P}^{\prime}$ - pressure difference due to the sorption of AITC, $\mathrm{kPa}$

$\mathrm{V}$ - volume of AITC, $\mathrm{m}^{3}$

$\mathrm{M}$ - molar mass of AITC, $\mathrm{g} \mathrm{kmol}^{-1}$

$\mathrm{M}_{\mathrm{g}}$ - grain mass, $\mathrm{kg}$

$\mathrm{R}^{\mathrm{g}}$ - universal gas constant, $8.314 \mathrm{~kJ} \mathrm{kmol}^{-1} \mathrm{~K}^{-1}$

$\mathrm{T}$ - absolute temperature, $\mathrm{K}$

The pressure difference due to the sorption of AITC and the volume of AITC into the glass flask were calculated using Eq. 3 and 4 respectively.

$$
\Delta \mathrm{P}^{\prime}=\Delta \mathrm{P}_{\mathrm{ATTC}}-\Delta \mathrm{P}_{\mathrm{S}}
$$

in which:

$\Delta \mathrm{P}_{\text {AITC }}$ - pressure difference of the system in the presence of AITC, $\mathrm{kPa}$

$\Delta \mathrm{P}_{\mathrm{S}}$ - pressure difference of the system without the presence of the AITC, $\mathrm{kPa}$

$$
V=V_{f}-\frac{M_{g}}{\rho b}
$$

in which:

$$
\begin{array}{ll}
V_{f} & - \text { flask volume, } \mathrm{m}^{3} \\
\rho_{\mathrm{b}} & \text { - bulk density of grains, } \mathrm{kg} \mathrm{m}^{-3}
\end{array}
$$

Kinetic models of zero, first and second order (Table 1) were fitted to the AITC concentration data obtained by Eq. 2 .

Table 1. Kinetic models and the respective differential and integrated equations

\begin{tabular}{ccc}
\hline Models & Differential equation & Integrated equation \\
Zero order & $\frac{\mathrm{d}[\mathrm{C}]}{\mathrm{dt}}=-\mathrm{k}$ & {$[\mathrm{C}]=\left[\mathrm{C}_{0}\right]-\mathrm{kt}$} \\
First order & $\frac{\mathrm{d}[\mathrm{C}]}{\mathrm{dt}}=-\mathrm{k}[\mathrm{C}]$ & $\ln [\mathrm{C}]=\ln \left[\mathrm{C}_{0}\right]-\mathrm{kt}$ \\
Second order & $\frac{\mathrm{d}[\mathrm{C}]}{\mathrm{dt}}=-\mathrm{k}[\mathrm{C}]^{2}$ & $\frac{1}{[\mathrm{C}]}=\frac{1}{\left[\mathrm{C}_{0}\right]}+\mathrm{kt}$ \\
\hline
\end{tabular}

Source: Wright (2004)

in which:

$\mathrm{C}_{0}$ - initial AITC concentration per unit of grains mass, $g$ $\mathrm{kg}^{-1}$

t - time, s

$\mathrm{k}$ - sorption rate, $\mathrm{s}^{-1}$

The analysis of the goodness of fit of the kinetic models (Table 1) was performed by means of regression analysis, using the computational software SigmaPlot 2001 version 7.0 for Windows. The highest value of the determination coefficient $\left(\mathrm{R}^{2}\right)$ was taken into account for the selection of kinetic models. The utilization of the determination coefficient as selection parameter lies in the fact that the kinetic models of zero, first and second orders are models of simple linear regression.

\section{Experimental procedure for determination of effective diffusion coefficient}

In order to determine the effective diffusion coefficient of AITC, a prototype was utilized; this prototype was composed of a cylindrical column with $15 \mathrm{~cm}$ of diameter and $47 \mathrm{~cm}$ of height, and a gas chamber with $30 \mathrm{~cm}$ of diameter and $22 \mathrm{~cm}$ of height, both made of stainless steel. At the base of the cylindrical column, a metallic screen was placed for the support of the grains and the formation of a plenum for better distribution of the gas. Gas sampling holes were drilled radially at $5.0 \mathrm{~cm}$ interval at seven points of the column. The holes were arranged helicoidally so that there were no interferences among the sample collections. The holes were sealed with a silicone septum.

Maize grains were conditioned into a cylindrical column, and a beaker of $100 \mathrm{~mL}$ containing $40 \mathrm{~mL}$ of essential mustard oil was placed inside the gas chamber. Preliminary tests showed that the essential mustard oil remained in the liquid phase for $24 \mathrm{~h}$ and released enough quantity of AITC to maintain constant concentration in the air, indicating saturation state of the air by the AITC. After the $24 \mathrm{~h}$ period, a valve connected between the column and the chamber was opened, allowing the diffusion of AITC through the maize grains. At the interval of $110 \mathrm{~min}, 2.0$ $\mathrm{mL}$ of intergranular air was collected from the seven points of the cylindrical column. At the intervals of each sampling in the cylindrical column, samples in the gas chamber were also collected by means of a rubber septum. The collected samples were immediately injected in the gas chromatograph (GC), coupled to a masses spectrometer (MS) GC/MS (Shimadzu, model QP 5000).

\section{Diffusion model}

The unsteady one dimensional diffusion equation, in which the term referred to the sorption rate was included, was used to determine the effective diffusion coefficient of AITC through maize grains (Eq. 5). The term referring to the sorption rate was represented by the first order kinetic model.

$$
\frac{\partial \mathrm{C}}{\partial \mathrm{t}}=\mathrm{D}_{\mathrm{ef}} \frac{\partial^{2} \mathrm{C}}{\partial \mathrm{x}^{2}}-\mathrm{kC}
$$

in which:

C - nondimensional AITC concentration

$\mathrm{D}_{\text {ef }}$ - effective diffusion coefficient, $\mathrm{cm}^{2} \mathrm{~s}^{-1}$

$\mathrm{t}$ - time, $\mathrm{s}$

$\mathrm{X}$ - position, $\mathrm{cm}$

The effective diffusion coefficient depends upon the properties of the porous medium, such as porosity and tortuosity. In this case, the referred coefficient for porous medium is given by Eq. 6 (Cremasco, 2002).

$$
\mathrm{D}_{\mathrm{ef}}=\mathrm{D} \frac{\varepsilon}{\tau}
$$

in which: 
D - diffusion coefficient, $\mathrm{cm}^{2} \mathrm{~s}^{-1}$

$\varepsilon \quad$ - nondimensional porosity

$\tau$ - nondimensional tortuosity

Eq. 5 represents several phenomena of mass transport in porous medium, as exemplified by the fumigation process. This is due to the fact that the differential equation has a general solution. The specific solution that describes the physical phenomenon being studied is defined by initial condition (Eq. 7) and boundary conditions (Eq. 8a and 8b).

$$
\begin{aligned}
& C(x, 0)=0 \\
& C(0, t)=1 \\
& C(h, t)=0
\end{aligned}
$$

in which:

$\mathrm{C}(\mathrm{x}, 0)$ - initial nondimensional AITC concentration

$\mathrm{C}(0, \mathrm{t})$ - nondimensional AITC concentration at the base of porous media in determined time $t$

$\mathrm{C}(\mathrm{h}, \mathrm{t})$ - nondimensional AITC concentration at the end of column in determined time $t$

$\mathrm{H}$ - length of the porous media, $\mathrm{cm}$

The initial condition (Eq. 7) establishes that the porous medium is free from the AITC to be studied, in any position at time zero. The first boundary condition (Eq. 8a) establishes that the AITC concentration, at the base of the porous medium, is constant and equal to the concentration inside the gas chamber; the second boundary condition (Eq. 8b) determines that the AITC concentration in the upper part of the column is zero. Both the first and the second boundary conditions were established with the purpose of ensuring the concentration gradient that is the motive force for the occurrence of diffusion between the base and the upper parts of the column. At the upper part of the column, on the other hand, the AITC concentration is zero due to rapid diffusion in a gaseous medium, such as atmospheric air, in relation to the porous medium.

In order to solve the diffusion model (Eq. 5, 7, 8a and 8b), the following analytical solution was assumed (Polyanin, 2002):

$$
C(x, t)=D_{e f} \int_{0}^{t} H_{1}(x, t-\tau) d \tau
$$

in which:

$$
\mathrm{H}_{1}(\mathrm{x}, \mathrm{t})=\left.\frac{\partial}{\partial \xi} \mathrm{G}(\mathrm{x}, \xi, \mathrm{t})\right|_{\xi=0}
$$

and

$$
\mathrm{G}(\mathrm{x}, \xi, \mathrm{t})=\frac{2}{\mathrm{~h}} \operatorname{expkt} \sum_{\mathrm{n}=1}^{\infty} \operatorname{sen}\left(\frac{\mathrm{n} \pi \mathrm{x}}{\mathrm{h}}\right) \operatorname{sen}\left(\frac{\mathrm{n} \pi \xi}{\mathrm{h}}\right) \exp \left(-\frac{\mathrm{D}_{\mathrm{ef}} \mathrm{n}^{2} \pi^{2} \mathrm{t}}{\mathrm{h}^{2}}\right)
$$

The porosity, temperature and moisture content of the maize grains were assumed as being constant throughout the experiment. Eq. 9 was used for a determined effective diffusion coefficient when the theoretical AITC concentration was obtained, and it was compared with the concentration measured experimentally. In that way, the effective diffusion coefficient of AITC through maize grains was obtained using its variation, having as criterion the lowest difference between experimental and theoretical concentrations. The effective diffusion coefficient was assumed as the average of effective diffusion coefficient values obtained experimentally at each position and time.

\section{RESULTS AND DISCUSSION}

The reduction of AITC concentration during fumigation, as a function of the exposure period due to the sorption of gas by maize grains, is shown in Figure 1. The allyl isothiocyanate concentration ranged from $130.50 \mathrm{~g} \mathrm{~kg}^{-1}$ at the beginning of the experiment to $0.88 \mathrm{~g} \mathrm{~kg}^{-1}$ after $130 \mathrm{~min}$ of exposure of maize grains to gas. This reduction corresponded to $99 \%$ in relation to the initial AITC concentration. It was also observed (Figure 1) that $90 \%$ of the AITC concentration reduction occurred during the first $70 \mathrm{~min}$ of exposure and only $9 \%$ occurred in the remaining $60 \mathrm{~min}$ of exposure of maize grains to the gas. Results obtained by Isikber et al. (2002) during study on propylene oxide (PPO) as an alternative to fumigant methyl bromide corroborate this study. The authors verified a fast reduction of propylene oxide concentration after $60 \mathrm{~min}$ of exposure to grains of wheat, maize and cocoa, followed by a slower reduction. In addition, according to authors, the propylene oxide concentration reduction was faster in maize grains, which may indicate the effect of grain characteristics on the sorption phenomenon.

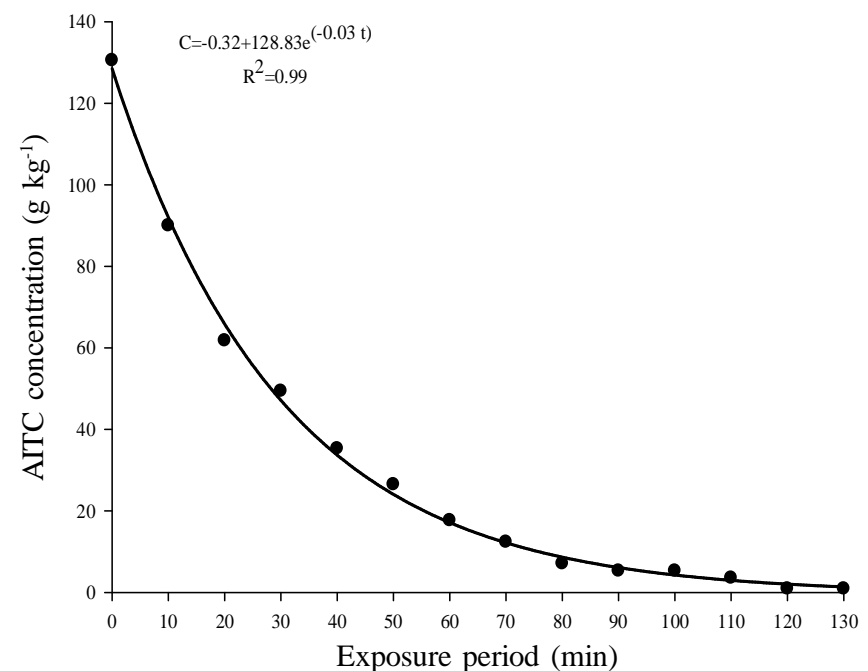

Figure 1. Reduction of AITC concentration in maize grains as a function of exposure period

Based on the data obtained of AITC concentration, kinetic models were fitted (Table 1) and coefficients of determination of each model were obtained (Table 2). Considering the 
determination coefficient as a comparison parameter among the models, it was observed that the best degree of adjustment was obtained with the first order kinetic model, in which the AITC sorption rate was $6.26 \times 10^{-4} \mathrm{~s}^{-1}$ and the neperian logarithm of initial AITC concentration was $5.01 \mathrm{~g} \mathrm{~kg}^{-1}$. The first order kinetic model was utilized to determine the sorption rate of methyl bromide in dried fruits (Hilton \& Banks, 1997) and carbonyl sulfide in stored commodity type such as cereals, grains, oil seeds and dried fruits (Weller, 2002).

Table 2. Kinetic models as a function of exposure period with their respective determination coefficients

\begin{tabular}{ccc}
\hline Models & Integrated equation & $\mathbf{R}^{2}$ \\
Zero order & $\mathrm{C}=84.88-0.01 \mathrm{t}$ & 0.76 \\
First order & $\operatorname{In}[\mathrm{C}]=5.01-6.26 \times 10^{-4} \mathrm{t}$ & 0.97 \\
Second order & $1 /[\mathrm{C}]=-0.21+1.16 \times 10^{-4} \mathrm{t}$ & 0.56 \\
\hline
\end{tabular}

In order to demonstrate the goodness of fit of the first order kinetic model in describing the experimental data, the curve of this model was plotted (Figure 2). Considering that the reduction of neperian logarithm of AITC concentration with increase in exposure period is attributed to sorption mechanism, the inverse relationship between the neperian logarithm of concentration and the exposure period indicates to what extent the gas is being absorbed by the maize grains during the fumigation process.

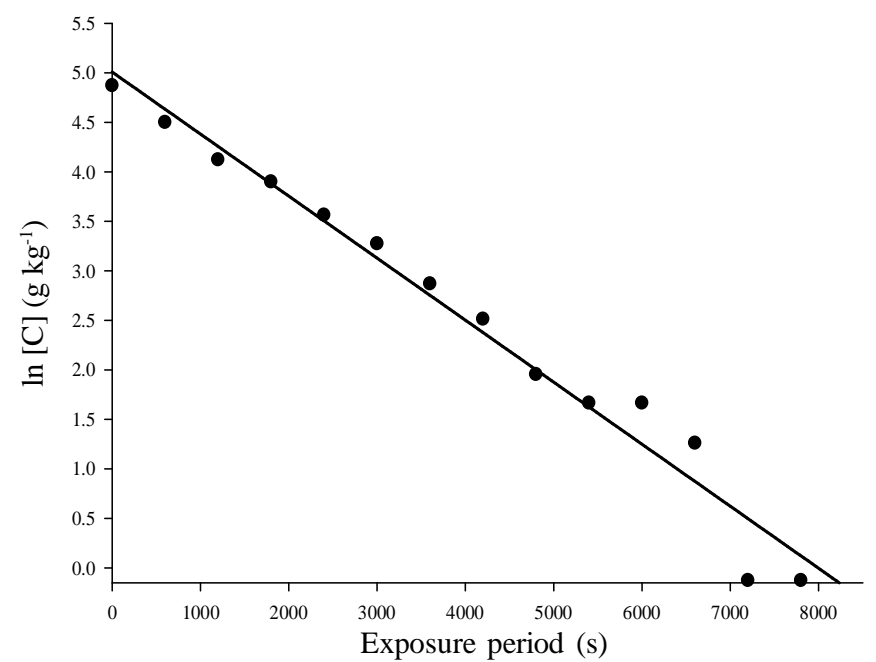

Figure 2. Curve of the first order kinetic model

The effective diffusion coefficient of AITC through maize grains, as determined by the diffusion model (Eq. 5, 7, 8a and $8 b$ ), was $7.2 \times 10^{-3} \mathrm{~cm}^{2} \mathrm{~s}^{-1}$. It is noteworthy that no research on the determination of effective diffusion coefficient of AITC through grain bulks was available in the specialized literature. Nevertheless, it is possible to utilize the effective diffusion coefficient of other gases for comparison purposes. The effective diffusion coefficient values of carbon dioxide were reported by Singh et al. (1984); the porous medium used in their study was rapeseed, wheat, maize and oat; by Singh et al. (1985) for wheat, and by Shunmugam et al. (2005) when the porous medium was wheat, barley and canola bulks. These authors verified that the effective diffusion coefficient of carbon dioxide showed an order of magnitude of $10^{-2} \mathrm{~cm}^{2} \mathrm{~s}^{-1}$. Comparing that value with the one obtained from this study $\left(7.2 \times 10^{-3} \mathrm{~cm}^{2} \mathrm{~s}^{-1}\right)$, it was verified that the order of magnitude of effective diffusion coefficient of AITC was 10 times lower than that of carbon dioxide.

The transport by diffusion of gas through grain bulks and, consequently, the effective diffusion coefficient shows a strong dependence upon properties of the gas, such as molecular mass and density in relation to the air. The difficulty of gas movement through porous medium due to high molecular mass and density implies reduction of the effective diffusion coefficient. The relationship between diffusion and gas density is clearly observed in Graham's Diffusion Law, which states that diffusion velocity is inversely proportional to the square root of gas density (Cremasco, 2002). Therefore, the low value of the effective diffusion coefficient of allyl isothiocyanate, when compared to that of carbon dioxide, can be explained through the difference of the molecular mass and density of those gases. The molecular mass of AITC $\left(99.15 \mathrm{~g} \mathrm{~mol}^{-1}\right)$ is 2.25 times larger than that of carbon dioxide $\left(44.00 \mathrm{~g} \mathrm{~mol}^{-1}\right)$ and the carbon dioxide density in relation to the air (1.5) is lower than that of allyl isothiocyanate (3.4).

Still for comparison purposes, based on the values of diffusion coefficient in the air of gaseous compounds of molecular mass close to that of AITC, the effective diffusion coefficient of those compounds can be calculated using Eq. 6 . The values of the diffusion coefficient in the air at temperature of $25^{\circ} \mathrm{C}$ and atmospheric pressure of compounds of molecular mass close to that of AITC, such as aniline and benzene chloride were reported by Coulson \& Richardson (2004). For the calculation of the effective diffusion coefficient of aniline and benzene chloride (Eq. 6), tortuosity values equal to 4.0 (Knudsen et al., 1997) and porosity of maize equal to 0.4 were considered. The value of the bulk density and true density of grains for calculated the porosity was $720 \mathrm{~kg} \mathrm{~m}^{-3}$ and $1210 \mathrm{~kg} \mathrm{~m}^{-3}$, respectively. The effective diffusion coefficients and molecular masses of gases values analogous to allyl isothiocyanate are shown in Table 3. It can be verified that the effective diffusion coefficient of AITC is coherent with the effective diffusion coefficient of both aniline and benzene chloride.

Table 3. Effective diffusion coefficients and the molecular masses of the gases

\begin{tabular}{|c|c|c|}
\hline Gas & $\begin{array}{c}\text { Molecular mass } \\
\left(\mathrm{g} \mathrm{mol}^{-1}\right)\end{array}$ & $\begin{array}{c}\text { Effective diffusion } \\
\text { coefficient }\left(\times 10^{-3} \mathrm{~cm}^{2} \mathrm{~s}^{-1}\right)\end{array}$ \\
\hline Aniline $^{1}$ & 93.13 & 7.20 \\
\hline Allyl is othiocyanate & 99.15 & 7.20 \\
\hline Benzene chlorine ${ }^{1}$ & 112.56 & 7.30 \\
\hline
\end{tabular}

\section{Conclusions}

1. The transportation of AITC through the mass of grains is slow due to the low value of the effective diffusion coefficient and the high sorption rate of this component by the grains.

2. A possibility for the application in grain bulks is the manufacturing of AITC sachets. Another possibility for application of AITC in the mass of grains is to introduce this gas in association with the aeration system. 


\section{ACKNOWLEDGEMENTS}

The authors would like to thank CAPES Foundation, for the financial support.

\section{LITERATURE CITED}

Alagusundaram, K.; Jayas, D. S.; Muir, W. E.; White, N. D. G.; Sinha, R. N. Finite element model of three-dimensional movement of carbon dioxide in grain bins. Canadian Agricultural Engineering, v.38, p.75-82, 1996.

Almeida, F. de A. C.; Almeida, S. A. de; Santos, N. R. dos; Gomes, J. P.; Araújo, M. E. R. Efeito de extratos alcoólicos de planta sobre o caruncho de feijão vigna (Callosobruchus maculatus). Revista Brasileira de Engenharia Agrícola e Ambiental, v.9, p.585-590, 2005.

ASAE - American Society of Agricultural Engineers. S352.2: Moisture measurement - Unground grain and seeds. In: ASAE standards, D245.5: Moisture relationships of plantbased agricultural Products, 47.ed. St. Joseph: American Society of Agricultural Engineers. 2000. 563p.

Bell, C. H. Fumigation in the $21^{\text {st }}$ century. Crop Protection, v. 19 , p.563-569, 2000.

Capps, A. L. A. P.; Novo, J. P. S.; Novo, M. C. S. S. Repelência e toxicidade de Cyperus iria L., em início de florescimento, ao gorgulho Sitophilus oryzae. Revista Brasileira de Engenharia Agrícola e Ambiental, v. 14, p.203-209, 2010.

Coulson, J. M.; Richardson, J. F. Tecnologia química - Fluxo de fluidos, transferência de calor e transferência de massa. 4.ed. Lisboa: Fundação Calouste Gulbenkian, 2004. 896p.

Cremasco, M. A. Fundamentos de transferência de massa. 2.ed. São Paulo: UNICAMP, 2002. 729p.

Dhingra, O. D.; Costa, M. L. N.; Silva, G. J.; Mizubuti, E. S. G. Essential oil of mustard to control Rhizoctona solani seedling damping off and seedling blight in nursery. Fitopatologia Brasileira, v.29, p.683-686, 2004.

Hilton, S. J.; Banks, H. J. Methyl bromide sorption and residues on sultanas and raisins. Journal of Stored Products Research, v.33, p.231-249, 1997.

Isikber, A. A.; Navarro, S.; Finkelman, S.; Azrieli, A.; Rindner, M; Dias, R. Propylene oxide as a potential alternative to methyl bromide. In: Credland, P. F.; Armitage, D. M.; Bell, C. H.; Cogan, P. M.; Highley, E. Advances in stored product protection. York: CABI Publishing, 2002. v.1, p.823-826.

Isshiki, K.; Tokuora, K.; Mori, R.; Chiba, S. Preliminary examination of allyl isothiocyanate vapor for food preservation. Bioscience, Biotechnology and Biochemistry, v.56, p.1476-1477, 1992.

Knudsen, J. G.; Hottel, H. C.; Sarofim, A. F.; Wankat, P. C.; Knaebel, K. S. Heat and mass transfer. In: Perry, R. H.; Green, D. W.; Maloney, J. O. Perry's chemical engineers' handbook. 7.ed. Nova York: McGraw-Hill Inc, 1997. cap. 5, p.1-80.

Mari, M.; Bertolini, P.; Pratella, G. C. Non-conventional methods for the control of post-harvest pear diseases. Journal of Applied Microbiology, v.94, p.761-766, 2003.

Mohsenin, N. N. Physical properties of plant and animal materials. 2.ed. New York: Gordon and Breach Publishers, 1986. 891p.
Moreira, S. M.; Chaves, M. A.; Oliveira, L. M. Comparação da eficiência líquida na determinação da massa específica aparente de grãos agrícolas. Revista Brasileira de Armazenamento, v.9, p.22-24, 1984/1985.

Negahban, M.; Moharramipour, S.; Sefidkon, F. Fumigant toxicity of essential oil from Artemisia sieberi Besser against three stored-product insects. Journal of Stored Products Research, v.43, p.123-128, 2007.

Papachristos, D. P.; Stamopoulos, D. C. Fumigant toxicity of three essential oils on the eggs of Acanthoscelides obtectus (Say) (Coleoptera: Bruchidae). Journal of Stored Products Research, v.40, p.517-525, 2004.

Pereira, A. de M.; Faroni, L. R. A.; Sousa, A. H. de; Urruchi, W. I.; Paes, J. L. Influência da temperatura da massa de grãos sobre a toxicidade do ozônio a Tribolium castaneum. Revista Brasileira de Engenheira Agrícola e Ambiental, v.12, p.493497, 2008.

Pimentel, M. A. G.; Faroni, L. R. A.; Tótola, M. R.; Guedes, R. N. C. Phosphine resistance, respiration rate and fitness consequences in stored-product insects. Pest Management Science, v.63, p.876-881, 2007.

Polyanin, A. D. Handbook of linear partial differential equations for engineers and scientists. New York: Chapman \& Hall/ CRC, 2002. 665p.

Rozado, A. F.; Faroni, L. R. A.; Urruchi, W. M. I.; Guedes, R. N. C; Paes, J. L. Aplicação de ozônio contra Sitophilus zeamais e Tribolium castaneum em milho armazenado. Revista Brasileira de Engenharia Agrícola e Ambiental, v.12, p.282285, 2008.

Shunmugam, G.; Jayas, D. S.; White N. D. G; Muir, W. E. Diffusion of carbon dioxide through grain bulks. Journal of Stored Products Research, v.41, p.131-144, 2005.

Singh, D.; Muir, W. E.; Sinha, R. N. Apparent coefficient of diffusion of carbon dioxide through cereals and rapeseed. Journal of Stored Products Research, v.20, p.169-175, 1984.

Singh, D.; Muir, W. E.; Sinha, R. N. Transiente method to determine the diffusion coefficient of gases. Canadian Agricultural Engineering, v.27, p.69-72, 1985.

Tsao, R.; Peterson, C. J.; Coats, J. R. Glucosinolate breakdown products as insect fumigants and their effect on carbon dioxide emission of insects. BioMed Central Ecology, v.2, p.1-7, 2002.

Weller, G. L. Sorption of carbonyl sulfide by stored products. In: Credland, P. F.; Armitage, D. M.; Bell, C. H.; Cogan, P. M.; Highley, E. Advances in stored product protection. York: CABI Publishing, 2002. v.1, p.493-497.

Worfel, R. C.; Schneider, K. S.; Yang, T. C. S. Suppressive effect of allyl isothiocyanate on population of stored grain insect pests. Journal of Food Processing and Preservation, v.21, p.9-19, 1997.

Wright, M. R. An introduction to chemical kinects. 1.ed. New York: John Wiley \& Sons Ltd, 2004. 441p.

Wu, H.; Zhang, G.; Zeng, S.; Lin, K. Extraction of allyl isothiocyanate from horseradish (Armoracia rusticana) and its fumigant insecticidal activity on four stored product pests of paddy. Pest Management Science, v.65, p.1003-1008, 2009.

Zettler, J. L.; Arthur, F. H. Chemical control of stored product insects with fumigants and residual treatments. Crop Protection, v.19, p.577-582, 2000. 